\section{The effect of audiovisual media use on the duration of exclu- sive breastfeeding in working mother}

\section{Uke Maharani Dewi, Yunik Windarti \\ Universitas Nahdlatul Ulama, \\ Surabaya, Indonesia}

\begin{abstract}
The success of breastfeeding for the first six months is a challenge that must be faced by working mothers. Workload and work stress sometimes become obstacles that cause irregular breastfeeding, rush and even boring and unpleasant activities. The purpose of this study was to analyze the effect of using audiovisual media on the duration of breastfeeding for working mothers. This research was conducted using the quasi-experimental method with the posttest control group design taking place in several workplace agencies in Wonokromo village area for the period FebruarySeptember 2018. The control group was working mothers who breastfeed without using audiovisual media and the case group was working mothers who breastfeed using audiovisual media. Data was collected by using observation sheets and bivariate analysis with independent sample $t$ test $\mathrm{p}=$ 0.02 . The conclusion of the results of this study is the use of audiovisual media influences the duration of exclusive breastfeeding in working mothers.
\end{abstract}

\section{Introduction}

The failure of exclusive breastfeeding for six months is often experienced by working mothers. ${ }^{1}$ The most common reason for the failure of exclusive breastfeeding in working mothers is insufficient breast milk production in more than $90 \%$ of cases, and $10 \%$ is due to infant disease and maternal disease. ${ }^{2}$ The causes of the lack of breast milk production in working mothers are because of the stress experienced by working mothers. ${ }^{3}$ Working mothers have higher stress levels than mothers who do not work. Stress can inhibit the production and secretion of lactating hormones. Disruption of production and secretion of lactation hormone will cause the least production of breast milk which ultimately affects the length of breastfeeding. ${ }^{4}$

The increase in oxytocin is triggered by the sound of crying and laughing babies, nipple suction during the breastfeeding. ${ }^{4}$ Listening to baby cries has been shown to increase prolactin levels in pregnant and lactating women. ${ }^{5}$ Increased serum prolactin has been shown when mothers breastfeed their babies. ${ }^{6}$ This stimulation is not possible for a mother who works and is separated from her baby during working hours. Even when milking in the workplace the mind is also difficult to avoid the workload.

This study aimed to analyze the effect of using audiovisual media on the duration of breastfeeding for working mothers. The audiovisual media contained videos of baby activities. Almost all mothers captured important events of their babies in their cellphones so they can be seen anywhere and anytime.

\section{Materials and Methods}

The study population was working mothers who had returned to work after maternity leave and obtained permission from their leaders to breastfeed at work. During working hours, the mother was separated from her baby (maximum working hours are ten hours). The age of the baby was between two and three months.

The audiovisual media used video recordings of baby activities stored on the personal cellphone of each working mother and seen at the start until the end of the milling activity. The research method used was quasi-experimental with a case-control approach. Samples were divided into two groups; the control group, and the case group. The control group is working mothers who breastfeed without using audiovisual media and the case group is working mothers who breastfeed using audiovisual media. The independent variable is the use of audiovisual media and the dependent variable is the duration of breastfeeding (duration of exclusive breastfeeding). Data was collected using observation sheets filled by respondents. Data analysis was performed using independent t-test.

\section{Results}

The survey results through the observation sheet are explained through Tables 1-3.

\section{Discussion}

The use of audiovisual media affects duration of exclusive breastfeeding. Although the interaction between mother and baby occurs indirectly, the bond is still formed and both babies-mother smiles. Oxytocin is a hormone that is conditioned on
Correspondence: Uke Maharani Dewi, Faculty of Nursing and Midwifery, Universitas Nahdlatul Ulama Surabaya, SMEA Street 57, Surabaya, Jawa Timur 60243, Indonesia

Te1.: +62.31.8291920 - Fax: +62.31 .8298582$

E-mail: uke@unusa.ac.id

Key words: audiovisual media, duration of breastfeeding, working mothers.

Acknowledgment: Thank you to Ristekdikti for providing funding for the implementation of this research (DIPA 042.06.1401516/ 2018).

Contributions: the authors contributed equally.

Conflict of interest: The authors declare that there are no potential conflicts of interest in this research.

Funding: Ristekdikti for providing funding for the implementation of this research (DIPA 042.06.1401516 / 2018).

Clinical trials: the study is registered in ethical committee of Universitas Nahdlatul Ulama Surabaya.

Conference presentation: part of this paper was presented at the $3^{\text {rd }}$ International Symposium of Public Health, 2018 October 31 - November 1, Universitas Airlangga, Surabaya, Indonesia

Dedication: the article is dedicated to my profession on the occasion of the $3 \mathrm{rd}$ International Symposium of Public Health, 2018 October 31- November 2, Surabaya, Indonesia

Received for publication: 28 July 2019.

Revision received: 9 September 2019.

Accepted for publication: 15 October 2019.

This work is licensed under a Creative Commons Attribution NonCommercial 4.0 License (CC BY-NC 4.0).

${ }^{\circ}$ Copyright: the Author(s), 2019

Licensee PAGEPress, Italy

Journal of Public Health in Africa 2019; 10(s1):1199 doi:10.4081/jphia.2019.1199

the mother's feelings, such as touching, kissing or seeing her baby, or hearing the cry of her baby, or thinking about it with affection.

In this study statistical parity did not significantly influence the duration of exclusive breastfeeding, but from the data obtained multiparous mothers gave more exclusive breastfeeding for $>6$ months. Multipara mothers are considered to have experience in giving breast milk to their 
babies and are better in overcoming difficulties in giving breast milk. The success of the previous breastfeeding is also a motivation for the success of subsequent breastfeeding. Primiparous mothers need to get support before and after the childbirth in order to be able to successfully breastfeed longer than multiparous mothers. ${ }^{7}$ Interventions for the success of exclusive breastfeeding must be oriented to the needs of each breastfeeding mother. ${ }^{8}$

The mothers who gave vaginal birth in the case group mostly gave exclusive breastfeeding $>6$ months. Vaginal delivery has a significant effect on the implementation of early breastfeeding initiation, not the duration of exclusive breastfeeding. ${ }^{9}$ The percentage of women who do not intend to breastfeed and not start breastfeeding at the cesarean section of labor is $7.4 \%$ and $4.3 \%$, whereas in women who give birth vaginally each is $3.4 \%$ and $1.8 \% .^{10}$ The type of work does not significantly influence the duration of exclusive breastfeeding. Significant differences in exclusive breastfeeding are between mothers working in the formal work sector $(16 \%)$ and informal $(84 \%)(p=0.020) .{ }^{11}$

The unavailability of lactation space in the workplace is not a barrier for working mothers to continue to provide exclusive breastfeeding. In this study, this did not significantly affect exclusive breastfeeding. However, the provision of special lactation rooms in the workplace affected the duration of breastfeeding. ${ }^{12}$

\section{Conclusions}

The duration of exclusive breastfeeding in working mothers is strongly influenced by comfort feelings when giving breast milk while at work. By utilizing audiovisual media as a stress relief during breastfeeding, it can increase the duration of exclusive breastfeeding.

\section{References}

1. Sharmin L, Chowdhury MAKA, Khatun $\mathrm{S}$, et al. Barriers to Exclusive Breastfeeding among Urban Mothers. Journal of Enam Medical College 2016;6(2):88-92.

2. Yaqub A, Gul S. Original Article Reasons For Failure Of Exclusive Breastfeeding In Children Less Than Six Months Of Age. Journal of Ayub Medical Collage Abbottabad 2013;25(1-2):165-167.

3. Shukla S, Jaiswal M, Agrahari K. A study on stress level among working and nonworking women. International Journal of Home Science 2017;3(1):349-357.
Table 1. Characteristics of respondents.

\begin{tabular}{|c|c|c|c|c|}
\hline \multirow[t]{2}{*}{ Characteristics } & \multicolumn{2}{|c|}{ Total } & \multicolumn{2}{|c|}{ Percentage (\%) } \\
\hline & Control & Case & Control & Case \\
\hline \multicolumn{5}{|l|}{ Parity } \\
\hline Primiparous & 6 & 5 & 40.0 & 33.3 \\
\hline Multiparous & 9 & 10 & 60.0 & 66.7 \\
\hline \multicolumn{5}{|l|}{ Type of labor } \\
\hline Vaginal delivery & 11 & 9 & 73.3 & 60.0 \\
\hline Cesarean Section & 4 & 6 & 26.6 & 40.0 \\
\hline \multicolumn{5}{|l|}{ Type of Work } \\
\hline Lecture & 8 & 5 & 53.3 & 33.3 \\
\hline Nurse & 3 & 1 & 20.0 & 6.67 \\
\hline Bank employees & 1 & 2 & 6.67 & 13.3 \\
\hline HRD & 0 & 3 & 0 & 20.0 \\
\hline Optical clerk & 1 & 3 & 6.67 & 20.0 \\
\hline Laboratory staff & 0 & 1 & 0 & 6.67 \\
\hline \multicolumn{5}{|c|}{ Availability of lactation rooms } \\
\hline Getting & 3 & 2 & 20.0 & 13.3 \\
\hline There is no & 12 & 13 & 80.0 & 86.7 \\
\hline \multicolumn{5}{|l|}{ Type of Pump } \\
\hline Manual & 4 & 9 & 26.6 & 60 \\
\hline Electric & 11 & 6 & 73.4 & 40 \\
\hline \multicolumn{5}{|c|}{ Duration of expressing breast pump } \\
\hline$<15$ minutes & 5 & 3 & 33.3 & 20.0 \\
\hline $15-30$ minutes & 10 & 12 & 66.7 & 80.0 \\
\hline
\end{tabular}

Table 2. Duration of exclusive breastfeeding.

\begin{tabular}{|c|c|c|c|c|}
\hline \multirow[t]{2}{*}{ Characteristics } & \multicolumn{4}{|c|}{ Duration of exclusive breastfeeding } \\
\hline & Control & Case & Control & Case \\
\hline \multicolumn{5}{|l|}{ Parity } \\
\hline Primiparous & 4 & 1 & 2 & 4 \\
\hline Multiparous & 2 & 0 & 7 & 10 \\
\hline \multicolumn{5}{|l|}{ Type of labor } \\
\hline Vaginal delivery & 5 & 3 & 6 & 6 \\
\hline Cesarean Section & 4 & 3 & 0 & 3 \\
\hline \multicolumn{5}{|l|}{ Type of job } \\
\hline Lecture & 2 & 2 & 6 & 3 \\
\hline Nurse & 2 & 1 & 1 & 0 \\
\hline Bank employees & 1 & 2 & 0 & 0 \\
\hline HRD & 1 & 1 & 0 & 2 \\
\hline Optical clerk & 0 & 2 & 1 & 1 \\
\hline Laboratory staff & 1 & 1 & 0 & 0 \\
\hline \multicolumn{5}{|c|}{ Availability of lactation rooms } \\
\hline Getting & 2 & 2 & 1 & 0 \\
\hline There is no & 4 & 6 & 8 & 7 \\
\hline \multicolumn{5}{|l|}{ Type of Pump } \\
\hline Manual & 2 & 3 & 2 & 6 \\
\hline Electric & 7 & 5 & 4 & 1 \\
\hline \multicolumn{5}{|c|}{ Duration of expressing breast pump } \\
\hline$<15$ minutes & 1 & 0 & 4 & 3 \\
\hline $15-30$ minutes & 7 & 8 & 3 & 4 \\
\hline
\end{tabular}

Table 3. Linear regression of respondent characteristics to the duration of exclusive breastfeeding.

\begin{tabular}{lc} 
Characteristics & P Value \\
Parity & 0.249 \\
Type of labor & 0.138 \\
\hline Type of job & 0.089 \\
Availability of lactation rooms & 0.348 \\
\hline Type of pump & 0.159 \\
Duration of expressing breast pump & 0.252 \\
\hline All characteristics of respondents have $P$ value $>0.05$, which means that it has no significant effect on the duration of exclusive breastfeed-
\end{tabular}

All characteristics of respondents have $\mathrm{P}$ value $>0.05$, which means that it has no significant effect on the duration of exclusive breastfeed- 
4. Dozier AM, Nelson A, Brownell E. The Relationship between Life Stress and Breastfeeding Outcomes among LowIncome Mothers. Advances in Preventive Medicine 2012:2012:902487. 10 pages. Available from: https://doi.org/ 10.1155/2012/902487. Accessed on: 12 January 2018.

5. Lambert G, Johansson M, Ågren H, et al. Reduced Brain Norepinephrine and Dopamine Release in TreatmentRefractory Depressive Illness: Evidence in Support of the Catecholamine Hypothesis of Mood Disorders. Arch Gen Psychiatry 2000;57(8):787-793.

6. Tarín JJ, Hermenegildo C, García-pérez MA, et al. Endocrinology and physiolo- gy of pseudocyesis. Reproductive Biology And Endocrinology 2013:11:112.

7. Hackman NM, Schaefer EW, Beiler JS, et al. Breastfeeding Outcome Comparison by Parity. Breastfeeding Medicine 2015;10(3):156-162.

8. Mohamed MJ, Ochola S, Owino VO. Comparison of knowledge, attitudes and practices on exclusive breastfeeding between primiparous and multiparous mothers attending Wajir District hospital, Wajir County, Kenya : a crosssectional analytical study. International Breastfeeding Journal 2018;13(11):110.

9. Yilmaz E, Ocal FD, Yilmaz ZV, et al. Early initiation and exclusive breastfeeding: Factors influencing the atti- tudes of mothers who gave birth in a baby-friendly hospital. Turk J Obstet Gynecol 2017;14:1-9.

10. Hobbs AJ, Mannion CA, Mcdonald SW, et al. The impact of caesarean section on breastfeeding initiation, duration and difficulties in the first four months postpartum. BMC Pregnancy and Childbirth 2016;16(90):1-9.

11. Nkrumah J. Maternal work and exclusive breastfeeding practice: a community based cross- sectional study in Efutu Municipal, Ghana. International Breastfeeding Journal 2017;12(10):1-9.

12.Tsai S. Impact of a BreastfeedingFriendly Workplace on an Employed Mother ' s Intention to Continue Breastfeeding After Returning to Work. Breastfeed Med. 2013;8:210-6. 